\title{
Penggunaan Citra Satelit Resolusi Tinggi Untuk Pembuatan Peta Dasar Skala 1:5.000 Kecamatan Ngadirojo, Kabupaten Pacitan
}

\author{
Hilda Arssy Wiga Cintya, Muhammad Taufik, dan Akbar Kurniawan \\ Departemen Teknik Geomatika, Fakultas Teknik Sipil dan Perencanaan, Institut Teknologi Sepuluh \\ Nopember (ITS) \\ e-mail: taufik_m@geodesy.its.ac.id
}

\begin{abstract}
Abstrak-Indonesia adalah negara yang luas dengan pertumbuhan penduduk yang terus meningkat, sehingga pemerintah terus melakukan perencanaan dan pembangunan pagi kepentingan masyarakat. Langkah pertama yang harus bagi kepentingan masyarakat. Langkah pertama yang haru dilakukan dalam kegiatan perencanaan adalah menyediakan
informasi geospasial dasar atau peta dasar skala 1:5.000; untuk informasi geospasial dasar atau peta dasar skala 1:5.000; untuk perencanaan diguna un metode orthorektifikasi. Dalam hal ini diperlukan data GCP dan ICP yang diukur dengan GPS, dan data DEM yang dapa menunjang proses orthorektifikasi sehingga syarat sebagai peta dasar akan terpenuhi. Penelitian ini dilakukan di Kecamatan Ngadirojo, Kabupaten Pacitan dengan jumlah GCP sebanyak 11 titik dan ICP sebanyak 5 titik dengan sebaran 11 titik dan ICP sebanyak 5 titik dengan sebaran
memperhatikan kondisi tutupan lahan yang ada di citra satelit memperhatikan kondisi tutupan lahan yang ada di citra satelit Error dari GCP yang didapat sebesar 1,04 piksel dan hasil uji akurasi menghasilkan akurasi horizontal sebesar 2,168 meter sehingga memenuhi syarat untuk pembuatan peta dasar skala 1:5.000. Pada akhir penelitian ini dihasilkan sebanyak 15 lembar peta dasar skala 1:5.000.
\end{abstract}

Kata kunci-WorldView-2, DEM, Pengukuran GPS, Orthorektifikasi, Uji Akurasi.

\section{PENDAHULUAN}

TDONESIA merupakan negara kepulauan yang terdir dari luas daratan $1.922 .570 \mathrm{~km} 2$ dan luas perairan 3.257.483 $\mathrm{km}^{2}$ [1] dengan jumlah penduduk sebanyak 257.563.815 jiwa [2]. Distribusi kepadatan penduduk berkisar 56,81\% di Pulau Jawa pada tahun 2015 [3] sehingga, mewajibkan pemerintah terus menerus melakukan pembangunan bagi kepentingan penduduk di Indonesia Kegiatan pembangunan ini tidak bisa dilepaskan dari suatu bentuk pemanfaatan ruang baik di wilayah kabupaten, kota, kecamatan, hingga tingkat desa. Tentu saja pemanfaatan ruang wilayah Indonesia yang luas ini harus ditunjang dengan perencanaan tata ruang yang baik. Salah satu langkah perencanaan yaitu dengan menyiapkan informasi geospasial berupa peta yang dibutuhkan untuk sebuah kegiatan dalam pemanfaatan ruang.

Diantara peta yang akan dibutuhkan untuk sebuah kegiatan dalam pemanfaatan ruang antara lain adalah peta Rencana Detil Tata Ruang (RDTR) dengan informasi yang disesuaikan dengan kebutuhan pemanfaatan ruang yang akan dilakukan. Namun, penyediaan data peta RDTR ini tidak akan terlaksana apabila data peta dasar belum didapatkan.
Dimana, peta dasar merupakan peta garis yang menggambarkan posisi horizontal dan vertikal permukaan bumi dan benda tidak bergerak diatasnya yang dipakai sebagai dasar pembuatan peta - peta lainnya [4].

Kementerian Agraria dan Tata Ruang (ATR) melalui Ditjen Infrastruktur Perpetaan telah memprogramkan penyediaan peta dasar skala 1:5.000 untuk 219 lokasi atau setara dengan luasan $59.884,54 \mathrm{~km} 2$ di seluruh wilayah nusantara pada tahun 2015. Ketersediaan peta dengan spesifikasi yang sesuai kebutuhan merupakan prasyarat utama penyusunan RDTR [5]

Saat ini di Kecamatan Ngadirojo, Kabupaten Pacitan akan berlangsung sebuah program pemerintah yaitu program Lahan Pertanian Berkelanjutan (LP2B). Dan sesuai dengan Peraturan Pemerintah Republik Indonesia No. 25 Tahun 2012 tentang Sistem Informasi Lahan Pertanian Berkelanjutan disebutkan bahwa sebuah sistem informassi LP2B membutuhkan kegiatan penyediaan data dasar, dan data dasar tersebut berupa peta dasar.

Yang dimaksud peta dasar adalah peta yang diturunkan dari data penginderaan jauh dan survei lapangan serta memuat informasi dasar seperti batas administrasi, ketinggian dan kelerengan, penggunaan lahan pada saat peta diterbitkan, koordinat geografis dan dibuat dalam skala 1:10.000 atau lebih besar dan/atau disesuaikan dengan kedalaman skala dalam rencana tata ruang yaitu skala 1:5.000 [6]

Dengan mengacu pada Modul Validasi Peta Rencana Tata Ruang Modul I - IV Sumber Data dan Peta Dasar oleh BIG tahun 2016 [7] maka, penyediaan peta dasar dengan skala 1:5.000 Kecamatan Ngadirojo, Kabupaten Pacitan akan terealisasi.

\section{METODOLOGI PENELITIAN}

\section{A. Lokasi Penelitian}

Lokasi penelitian Studi ini berlokasi di Kecamatan Ngadirojo, Kabupaten Pacitan, Jawa Timur. Wilayah ini terletak pada koordinat $110^{\circ} 57^{\prime}-111^{\circ} 22^{\prime}$ Bujur Timur dan $7^{\circ} 45^{\prime}-8^{\circ} 16^{\prime}$ Lintang Selatan yang berbatasan dengan

- Sebelah Utara : Kecamatan Slahung, Kab. Ponorogo

- Sebelah Timur : Kecamatan Sudimoro

- Sebelah Selatan : Samudera Indonesia

- Sebelah Barat : Kecamatan Tulakan

Untuk penelitian kali ini, penulis menggunakan 1 scene citra 
WorldView-2 di Kecamatan Ngadirojo yang terletak pada koordinat $111^{\circ} 17^{\prime}-111^{\circ} 21^{\prime}$ Bujur Timur dan $8^{\circ} 11^{\prime}-8^{\circ}$ 16' Lintang Selatan.

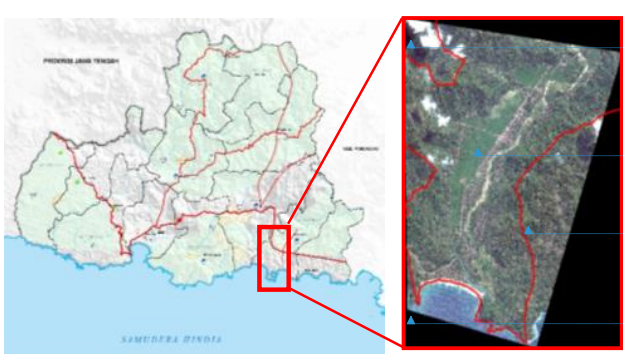

Gambar 1. Lokasi Studi: Kecamatan Ngadirojo

B. Data dan Peralatan

1) Data

Data yang dibutuhkan dalam Studi ini adalah:

1. Citra WorldView - 2 Kecamatan Ngadirojo, Kabupaten Pacitan.

2. Peta Kontur RBI skala 1:25.000 Kecamatan Ngadirojo, Kabupaten Pacitan.

3. Data pengukuran GPS Kecamatan Ngadirojo, Kabupaten Pacitan.

4. Data administrasi Kecamatan Ngadirojo, Kabupaten Pacitan.

2) Peralatan

Peralatan yang dibutuhkan dalam Studi ini adalah:

1. Perangkat Keras (Hardware)

a. Laptop

b. GPS Geodetik

2. Perangkat Lunak (Software)

a. Microsoft Office 2016

b. Topcon Tools v.8.2.3

c. ENVI 5.0

d. ArcMap 10.2

\section{Tahapan Pengolahan Data}

Tahapan pengolahan data pada penelitian ini adalah sebagai berikut:

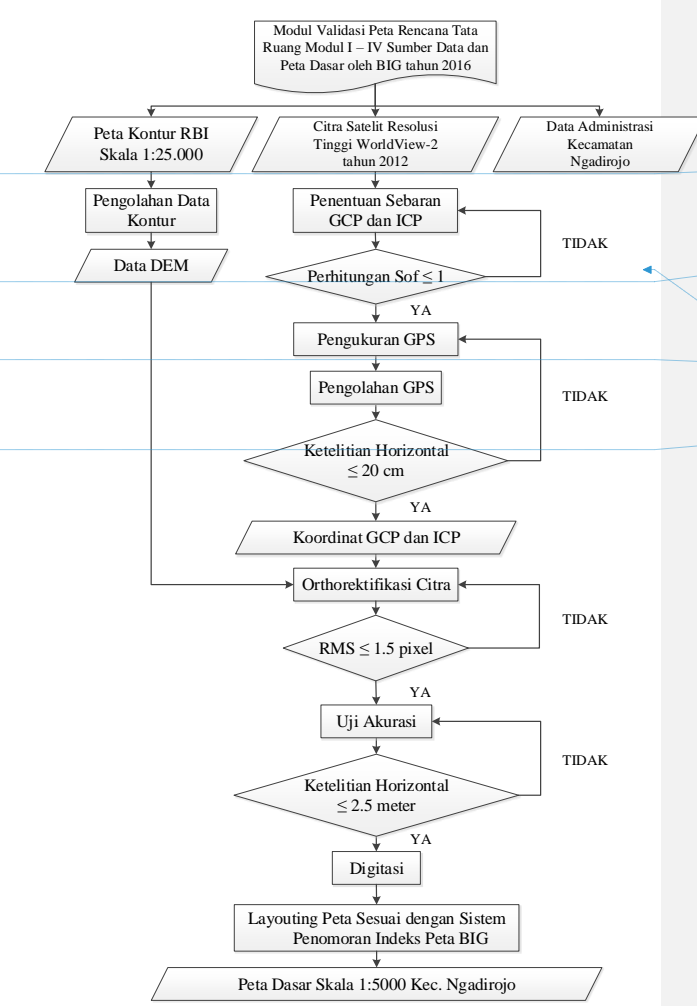

Gambar 2. Diagram Alir Penelitian

Berikut adalah penjelasan dari Metodologi Pengolahan Data yang beracuan pada Modul Validasi Peta Rencana Tata Ruang Modul I - IV Sumber Data dan Peta Dasar oleh Badan Informasi Geospasial tahun 2016: Pengumpulan Data

1. Pengumpulan Data

Pada tahap ini dilakukan pengumpulan data yang diperlukan untuk penelitian. Adapun data yang diperlukan antara lain Citra Satelit Resolusi Tinggi WorldView - 2 Kecamatan Ngadirojo tahun 2012, Peta Kontur RBI skala 1:25.000 Kecamatan Ngadirojo, dan Data Administrasi Kecamatan Ngadirojo.

2. Penentuan Sebaran GCP dan ICP

Ditentukan sebaran GCP dan ICP yang disesuaikan dengan wilayah studi kasus dan mencakup seluruh wilayah secara merata yang terdiri dari $11 \mathrm{GCP}$ dan 5 ICP.

3. Perhitungan Sof $\leq 1$

Dilakukan perhitungan sof untuk mengetahui kekuatan jaring dari sebaran GCP yang sudah dibuat dengan hasil yang harus didapatkan yaitu $\leq 1$. Semakin kecil bilangan faktor kekuatan jaringan tersebut, maka akan semakin baik konfigurasi jaringan yang bersangkutan dan sebaliknya.

4. Pengukuran GPS

Setelah ditentukan sebaran titik kontrol maka, dilakukan pengukuran titik kontrol menggunakan GPS geodetik dengan metode statik.
Formatted: Font: 6 pt, Bold, Font color: White

Formatted: Font: 8 pt, Bold, Font color: White

Formatted: Centered

Formatted: Font: 7 pt, Bold, Font color: White

Formatted: Font: 7 pt, Bold, Font color: White 
5. Pengolahan Data GPS

Dilakukan pengolahan data GPS menggunakan perangkat lunak pengolah data GPS untuk mendapatkan koordinat titik dari 11 GCP dan 5 ICP. Dimana koordinat dari 11 GCP ini akan digunakan untuk proses orthorektifikasi.

6. Ketelitian Horizontal $\leq 20 \mathrm{~cm}$

Setelah dilakukan pengolahan data GPS harus didapatkan ketelitian horizontal sebesar $\leq 20 \mathrm{~cm}$ sesuai dengan Modul Validasi Peta Rencana Tata Ruang, Sumber Data dan Peta Dasar yang dikeluarkan BIG tahun 2016.

7. Pengolahan Peta Kontur

Dilakukan pengolahan peta kontur RBI skala 1:25.000 menjadi data DEM yang akan digunakan untuk proses orthorektifikasi.

8. Orthorektifikasi Citra

Dilakukan orthorektifikasi untuk mendapatkan citra tegak menggunakan perangkat lunak ENVI 5.0 yang akan menghasilkan citra tegak dengan metode RPC yang memerlukan metadata dari citra berupa file .RPB data DEM, dan koordinat dari GCP.

9. $\mathrm{RMS} \leq 1,5$ piksel

Indikator bahwa hasil orthorektifikasi memenuhi akurasi horizontal peta skala 1:5.000 yaitu RMS hasil orthorektifikasi sebesar $\leq 1,5$ piksel sesuai dengan Modul Validasi Peta Rencana Tata Ruang, Sumber Data dan Peta Dasar yang dikeluarkan BIG tahun 2016. Apabila hasil RMS tidak $\leq 1,5$ piksel maka, diulangi proses orthorektifikasi. Periksa apakah terdapat kesalahan pada input data atau pada pendeskripsian parameter piksel

10.Uji Akurasi

Dilakukan untuk mengetahui nilai ketelitian citra satelit yang telah mengalami orthorektifikasi. Pengujian ketelitian posisi mengacu pada perbedaan koordinat antara titik uji pada gambar atau peta dengan lokasi sesungguhnya dari titik uji pada permukaan tanah.

11. Ketelitian Horizontal $\leq 2,5 \mathrm{~m}$

Citra resolusi tinggi yang digunakan untuk sumber data peta dikatakan memenuhi standar peta dasar skal 1:5.000 apabila ketelitian horizontal $\leq 2,5 \mathrm{~m}$ sesua dengan Modul Validasi Peta Rencana Tata Ruang, Sumber Data dan Peta Dasar yang dikeluarkan BIG tahun 2016. Apabila besar ketelitian horizontal tidak sesuai maka dilakukan pengecekan kembali interpretasi titik ICP, jika setelah diperiksa hasil akurasi belum memenuhi syarat maka proses orthorektifikasi harus diulang.

12.Digitas

Merupakan proses konversi data analog ke dalam format digital dengan pembuatan layer - layer untuk objek atau unsur peta dasar skala 1:5.000. Digitasi dilakukan pada unsur penutup lahan, hidrografi, hipsografi, bangunan, transportasi dan utilitas, batas administrasi, serta toponimi yang didata dari data administrasi Kecamatan Ngadirojo.

13. Layouting Peta Sesuai dengan Sistem Penomoran Indeks Peta BIG

Citra yang telah dilakukan digitasi selanjutnya dilakukan proses layouting untuk memberi informas peta dan membagi peta sesuai dengan nomor lemba peta RBI yang mencakup wilayah citra pada skala 1:5.000.

14.Peta Dasar Skala 1:5.000 Kec. Ngadirojo

Di sajikan Peta Dasar Skala 1:5.000 Kecamatan

Ngadirojo sebagai hasil akhir penelitian ini.

\section{HASIL DAN ANALISA}

A. Pemilihan Lokasi dan Sebaran GCP

Pemilihan lokasi dan sebaran titik kontrol tanah dilakukan dengan cara melihat objek yang akan dijadikan titik kontrol harus dapat diidentifikasi secara jelas pada citra. Objek yang dipilih seperti sudut pertigaan jalan, ujung pagar, atau pojok bangunan. Objek yang dijadikan titik kontrol ditempatkan merata pada daerah pemetaan.

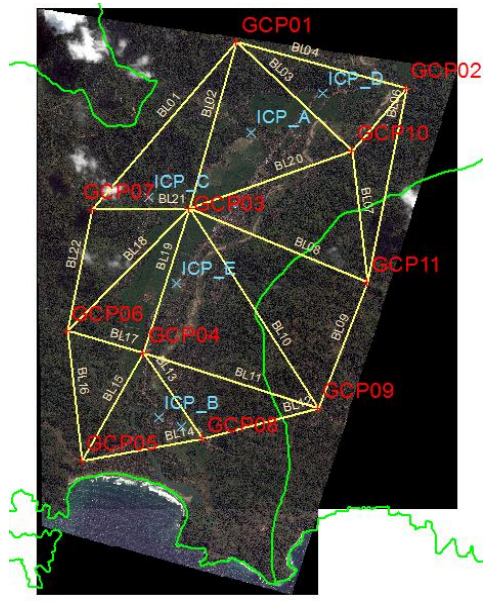

Gambar 3. Desain jaring GCP

Pada penelitian ini jumlah titik yang digunakan untuk perhitungan kekuatan jaring titik kontrol sebanyak 11 titik GCP dan 5 titik ICP. Pada desain jaring kontrol ini didapat nilai SoF sebesar 0.11293 didapat dari hitungan berikut:

Jumlah baseline : 22

Jumlah titik $: 11$

N_ukuran : Jumlah baseline $\mathrm{x} 3=66$

$\mathrm{N}$ parameter : Jumlah titik $\times 3=33$

u $\quad$ N_ukuran - N_parameter $=33$

$$
\text { SoF }=\frac{\operatorname{Trace}\left(\left[A^{T}\right] \cdot[A]\right)^{-1}}{u}=\frac{3.727}{33}=0,11293
$$

Semakin kecil bilangan faktor kekuatan jaring, maka akan semakin baik konfigurasi jaring yang bersangkutan, dan sebaliknya. Besar SoF yang dihasilkan jaring tersebut kurang dari 1 sehingga desain jaring SoF dianggap kuat.

\section{B. Hasil Pengukuran GCP dan ICP}

Dalam pengolahan data GPS ini terdapat ketentuan ketelitian horizontal sebesar $\leq 20 \mathrm{~cm}$. Sehingga dalam perangkat lunak pengolah GPS ditentukan besar akurasi horizontal sebesar $20 \mathrm{~cm}$ atau $0.2 \mathrm{~m}$. Koordinat GCP dan ICP ini diikatkan dengan koordinat CORS BIG di wilayah 
Pacitan dengan kode CPAC Berikut adalah hasil koordinat GCP dan ICP hasil pengolahan GPS:

\begin{tabular}{|c|c|c|c|}
\hline \multicolumn{4}{|c|}{$\begin{array}{c}\text { Tabel } 1 . \\
\text { Daftar Koordinat GCP dan ICP }\end{array}$} \\
\hline \multirow[t]{2}{*}{ No. } & \multirow{2}{*}{$\begin{array}{l}\text { Nama } \\
\text { Titik }\end{array}$} & \multicolumn{2}{|c|}{ "Koordinat Titik Kontrol } \\
\hline & & $\mathrm{X}(\mathrm{m})$ & $\mathrm{Y}(\mathrm{m})$ \\
\hline 1 & GCP01 & 535282.932 & 9094325.478 \\
\hline 2 & GCP02 & 538102.954 & 9093581.022 \\
\hline 3 & GCP03 & 534586.812 & 9091616.403 \\
\hline 4 & GCP04 & 533860.362 & 9089251.264 \\
\hline 5 & GCP05 & 532852.756 & 9087478.881 \\
\hline 6 & GCP06 & 532584.355 & 9089598.923 \\
\hline 7 & GCP07 & 532933.155 & 9091585.138 \\
\hline 8 & GCP08 & 534806.593 & 9087835.01 \\
\hline 9 & GCP09 & 536643.242 & 9088332,5 \\
\hline 10 & GCP10 & 537216.644 & 9092534.727 \\
\hline 11 & GCP11 & 537387.314 & 9090392,57 \\
\hline 12 & ICP_A & 535600.321 & 9092860.488 \\
\hline 13 & ICP_B & 534488.463 & 9088041.8 \\
\hline 14 & ICP_C & 533950.198 & 9091795.61 \\
\hline 15 & ICP_D & 536762.417 & 9093493.361 \\
\hline 16 & ICP_E & 534399.98 & 9090386.227 \\
\hline
\end{tabular}

Dan berikut hasil ketelitian horizontal yang ditunjukkan dengan RMS Error pada setiap titik. Dimana semua titik baik GCP maupun ICP menghasilkan ketelitian horizontal $\leq$ $20 \mathrm{~cm}$ atau $0.2 \mathrm{~m}$

Hasil ketelitian horizontal setiap titik diperoleh nilai residual antara 0,009-0,021 meter. Nilai residual ketelitian horizontal paling besar dihasilkan pada titik GCP yaitu GCP06 dan sedangkan pada titik ICP yaitu ICP_D. Nilai residual ini diakibatkan oleh noise sinyal GPS yaitu multipath dan cycle slips. Nilai residual ini dapat berpengaruh terhadap hasil orthorektifikasi yang akan dilakukan pada penelitian ini.

Tabel 2.

Daftar Ketelitian Horizontal GCP dan ICP

\begin{tabular}{ccl}
\hline \hline No. & $\begin{array}{c}\text { Nama } \\
\text { Titik }\end{array}$ & $\begin{array}{c}\text { Horz RMS } \\
(\mathrm{m})\end{array}$ \\
\hline 1 & GCP01 & 0.011 \\
2 & GCP02 & 0.014 \\
3 & GCP03 & 0.012 \\
4 & GCP04 & 0.015 \\
5 & GCP05 & 0.011 \\
6 & GCP06 & 0.02 \\
7 & GCP07 & 0.017 \\
8 & GCP08 & 0.017 \\
9 & GCP09 & 0.011 \\
10 & GCP10 & 0.016 \\
11 & GCP11 & 0.014 \\
12 & ICP_A & 0.02 \\
13 & ICP_B & 0.01 \\
14 & ICP_C & 0.009 \\
\hline \hline
\end{tabular}

\begin{tabular}{ccc}
\hline \hline No. & $\begin{array}{c}\text { Nama } \\
\text { Titik }\end{array}$ & $\begin{array}{c}\text { Horz RMS } \\
(\mathrm{m})\end{array}$ \\
\hline 15 & ICP_D & 0.021 \\
16 & ICP_E & 0.012 \\
\hline
\end{tabular}

Maka dapat disimpulkan dari data pengukuran GPS yang telah dilakukan, keseluruhan titik dapat digunakan untuk proses orthorektifikasi maupun uji akurasi citra dikarenakan hasil dari pengukuran GCP dan ICP diperoleh nilai residual untuk ketelitian horizontalnya antara 0,009-0,021 meter yang berarti hasil pengkuran dan pengolahan data GPS memenuhi standar dari Modul Validasi Peta Rencana Tata Ruang Modul I - IV Sumber Data dan Peta Dasar oleh BIG tahun 2016 .

\section{Hasil Pengolahan Data Kontur Menjadi data DEM}

Data kontur dari Peta Kontur RBI skala 1:25.000 yang merupakan jenis data vektor akan diolah menjadi data DEM dengan jenis data raster menggunakan perangkat lunak ArcMap 10.2. Berikut adalah data kontur dari peta kontur RBI skala 1:25.000 yang telah dipilih sesuai wilayah cakupan citra.

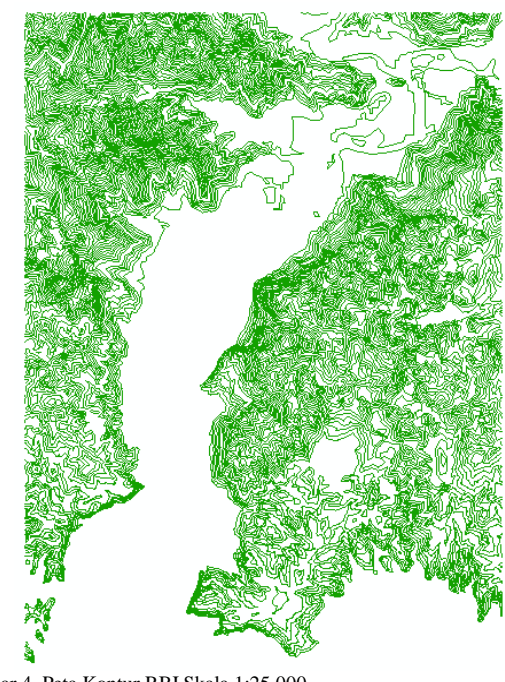

Gambar 4. Peta Kontur RBI Skala 1:25.000

Berikut adalah hasil data kontur yang telah menjadi data DEM dengan jenis data raster. Dengan semakin cerah warna maka semakin bertambah pula ketinggiannya. 


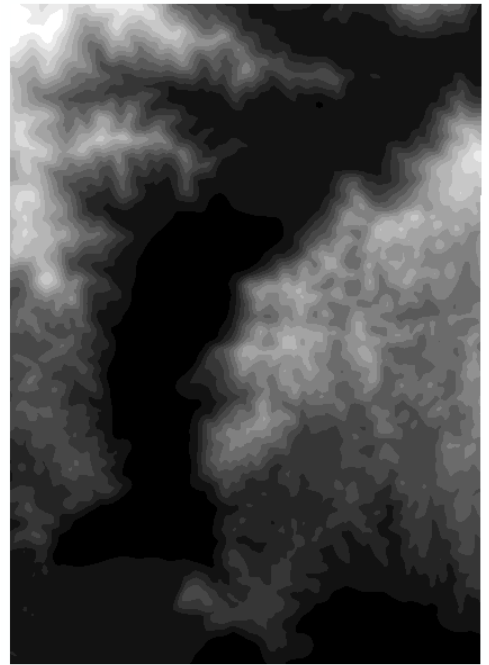

Gambar 5. DEM dari Peta Kontur RBI Skala 1:25.000

Data DEM yang dihasilkan dari peta kontur RBI skala 1:25.000 tidak memenuhi persayaratan ini tetapi, dapat digunakan untuk memenuhi informasi ketinggian maupun mengurangi pengaruh topografi akibat permukaan bumi yang berbukit pada citra satelit yang digunakan. Hal ini ditunjukkan dengan hasil orthorektifikasi yang memenuhi persyaratan BIG yaitu dihasilkan RMS Error sebesar $\leq 1,5$ piksel yang dapat dilihat dari pembahasan bagian 4.4 mengenai orthorektifikasi.

\section{Orthorektifikasi}

Orthorektifikasi dilakukan untuk mendapatkan citra tegak menggunakan perangkat lunak ENVI 5.0 dengan memasukkan 11 GCP yang menyebar di area citra. Indikator bahwa hasil orthorektifikasi memenuhi akurasi horizontal peta skala 1:5.000 yaitu RMS hasil orthorektifikasi sebesar $\leq$ 1,5 piksel menggunakan rumus sebagai berikut:

$$
R M S E=\sqrt{\frac{\left(x_{G P S}-x_{C P}\right)^{2}+\left(X_{G P S}-y_{C P}\right)^{2}}{n}}
$$

Berikut adalah hasil orthorektifikasi yang menghasilkan RMS Error sebesar 1,04481 piksel.

$$
\text { Tabel } 3 .
$$

Hasil Orthorektifikas

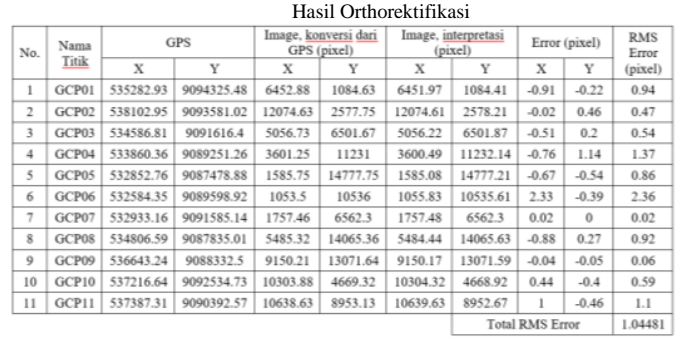

Pada pengolahan data pengukuran GPS dihasilkan nilai ketelitian yang paling besar pada GCP06 yaitu sebesar 0,02 meter. Sehingga, hal ini berdampak pada nilai RMS Error dari GCP06 yang menghasilkan nilai yang paling besar pula yaitu sebesar 2,36 piksel. Dan pada hasil pengolahan data DEM dari Peta Kontur RBI skala 1:25.000 dengan ketelitian 12,5 meter tidak memenuhi syarat dari BIG. Namun, pada jumlah total dari RMS Error dari hasil orthorektifikasi didapatkan hasil sebesar 1,04481 piksel yang artinya hasil orthorektifikasi ini memenuhi standar dari Modul Validasi Peta Rencana Tata Ruang Modul I - IV Sumber Data dan Peta Dasar oleh BIG tahun 2016 dengan RMS Error yang dihasilkan sebesar $\leq 1,5$ piksel. Sehingga, titik GCP06 dan data DEM dari Peta Kontur RBI skala 1:25.000 dapat digunakan untuk proses orthorektifikasi dan dapat dilanjutkan untuk tahap selanjutnya yaitu proses uji akurasi.

\section{E. Uji Akurasi}

Citra tegak yang dihasilkan dari proses orthorektifikasi dilakukan uji akurasi untuk mengetahui nilai ketelitian citra. Citra resolusi tinggi yang digunakan untuk sumber data peta dikatakan memenuhi standar peta dasar skala 1:5.000 apabila ketelitian horizontal $\leq 2,5 \mathrm{~m}$.

Uji akurasi dihitung dengan mencari RMS Error dari semua titik ICP terlebih dahulu kemudian dihitung dengan rumus sesuai dengan Pedoman Teknik Ketelitian Peta Dasar $^{[8]}$ berikut:

\section{Akurasi Horizontal = 1,5175 x RMS Error}

Hasil dari uji akurasi ini dihasilkan ketelitian horizontal sebesar $2.168202 \mathrm{~m}$. berikut adalah tabel uji akurasi:

Tabel 4

Hasil Uji Akuras

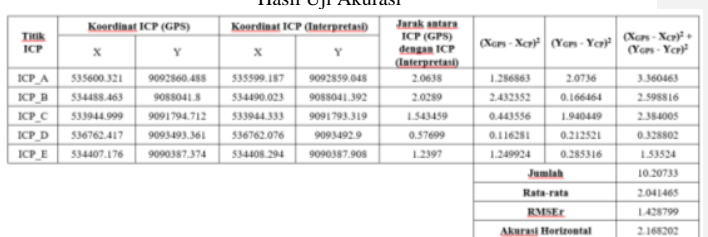

Dapat dilihat pada kolom Jarak antara ICP (GPS) dengan ICP (Interpretasi) pada ICP A dan ICP_B mempunyai jarak terjauh dari seluruh titik ICP yang digunakan yaitu masingmasing sebesar 1,8326 meter dan 1,6974 meter yang ditunjukkan gambar dibawah. Besarnya jarak ini menunjukkan ketidakcocokan antara ICP pada hasil pengukuran GPS dan ICP pada hasil interpretasi.

Hal ini berdampak pada hasil uji akurasi dari ICP A dan ICP_B karena dihasilkan nilai RMS Error yang besar yaitu masing-masing sebesar 3,360463 piksel dan 2,598816 piksel. Namun, pada proses uji akurasi ini didapat hasil uji akurasi sebesar 2,168202 meter yang artinya hasil uji akurasi ini memenuhi standar dari Modul Validasi Peta Rencana Tata Ruang Modul I - IV Sumber Data dan Peta Dasar oleh BIG tahun 2016 dengan ketelitian horizontal $\leq 2,5$ meter. Sehingga, baik ICP_A maupun ICP_B dengan nilai RMS Error yang besar dapat digunakan untuk proses uji akurasi. 
F. Digitasi dan Layouting Peta Dasar Skala 1:5.000

Citra tegak yang sudah dilakukan uji akurasi selanjutnya dilakukan digitasi terhadap tujuh unsur layer peta dasar yaitu tutupan lahan, hidrografi, hipsografi, transportasi dan utilitas, bangunan, batas administrasi, dan toponimi dari data administrasi Kecamatan Ngadirojo.

Berikut adalah salah satu hasil dari peta dasar Kecamatan Ngadirojo, Kabupaten Pacitan skala 1:5.000 yang telah dilakukan digitasi dengan NLP 1507 - 4415 - A.

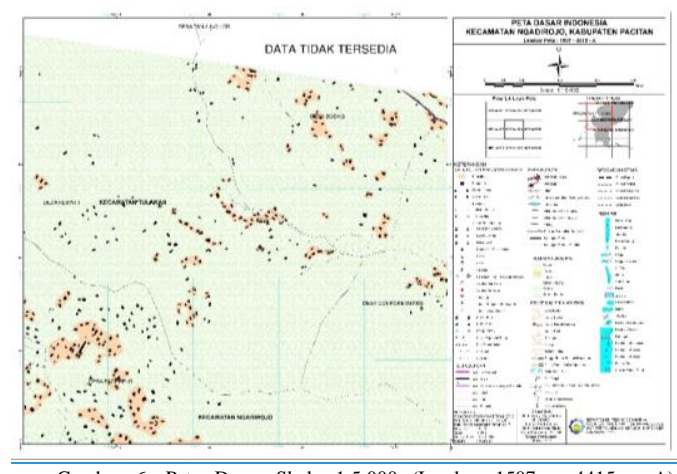

Gambar 6. Peta Dasar Skala 1:5.000 (Lembar 1507 - 4415 - A) Kecamatan Ngadirojo, Kabupaten Pacitan

Peta dasar ini dibagi sesuai dengan Nomor Lembar Peta (NLP) pada peta Rupa Bumi Indonesia (RBI). Citra yang digunakan pada penelitian ini bertampalan dengan peta RB skala 1:25.000 dengan NLP 1507 - 441 dan $1507-423$ Sesuai dengan Sistem Penomoran Indeks Peta oleh BIG peta dengan skala 1:25.000 akan dibagi menjadi 9 bagian NLP untuk peta skala 1:10.000. Kemudian, peta skala $1: 10.000$ akan dibagi menjadi 4 bagian NLP untuk menjadi peta skala 1:5.000 sehingga menghasilkan 15 lembar peta untuk Kecamatan Ngadirojo, Kabupaten Pacitan sesuai gambar dibawah.

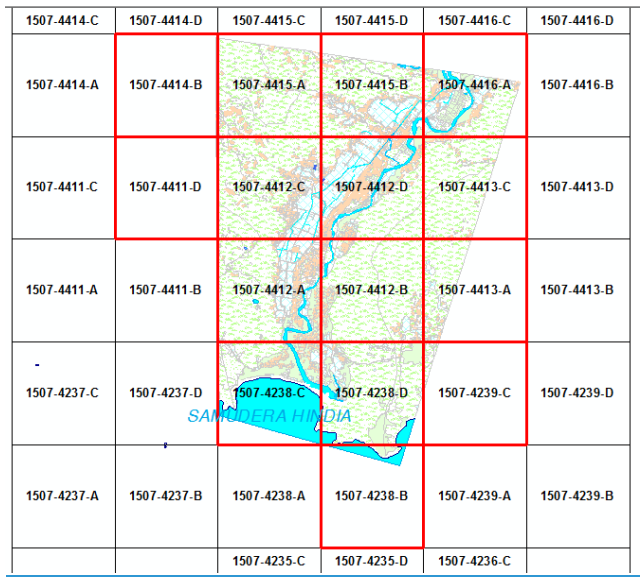

Gambar 7. Pembagian NLP pada Wilayah Penelitian

\section{KESIMPULAN}

Kesimpulan dari penelitian ini adalah:

1. Peta dasar skala 1:5.000 disediakan menggunakan citra satelit resolusi tinggi yang diolah melalui proses orthorektifikasi dengan syarat RMS Error yang dihasilkan sebesar 1,5 pixel dan hasil ketelitian horizontal dari uji akurasi sebesar 2,5 meter sesuai dengan Modul Validasi Peta Rencana Tata Ruang Modul I - IV Sumber Data dan Peta Dasar oleh BIG tahun 2016.

2. Proses orthorektifikasi menggunakan 11 titik koordinat GCP dengan metode RPC melalui perangkat lunak pengolah citra satelit, citra WorldView-2 didapatkan nilai RMSE sebesar 1,04 piksel sehingga hasil orthorektifikasi dapat diterima karena sesuai dengan Modul Validasi Peta Rencana Tata Ruang Modul I - IV Sumber Data dan Peta Dasar oleh BIG tahun 2016.

3. Desain titik GCP untuk proses orthorektifikasi yaitu mengikuti karakter dari objek dan luas wilayah yang tercover dalam citra, terdiri dari 11 titik GCP.

4. Sedangkan, pada uji akurasi citra WorldView-2 dengan menggunakan 5 titik uji ICP menghasilkan nilai sebesar 2,168 m sehingga hasil uji akurasi dapat diterima karena sesuai Modul Validasi Peta Rencana Tata Ruang Modul I - IV Sumber Data dan Peta Dasar oleh BIG tahun 2016.

\section{DAFTAR PUSTAKA}

R. Rumampuk, "Hak atas pengelolaan kawasan pesisir di

Provinsi Sulawesi Utara," Lex Soc., pp. 54-63. T. W.
http://data.worldbank.org/indicator/SP.POP.TOTL?locations=ID

B. P. Statistik, "Distribusi Persentase Penduduk menurut Provinsi," 2015.

B. S. Nasional, Spesifikasi Penyajian Peta Rupa Bumin - Bagian 2: Skala 1:25.000. Jakarta: Badan Standardisasi Nasional, 2010. K. A. D. T. R. / B. P. Nasional, Penyediaan Peta Dasar Harus Memperhatikan Kebutuhan RDTR. 2015

R. Indonesia, Peraturan Pemerintah Republik Indonesia Nomo 25 Tahun 2012 Tentang Sistem Informasi Lahan Pertanian Berkelanjutan. Jakarta: Kementerian Sekretariat Negara RI, 2012.

[7] Badan Informasi Geospasial, Modul Validasi Peta Rencana Tata Ruang. Jakarta, 2016 